\title{
New Zealand early childhood curriculum: The politics of collaboration
}

\section{Sandy Farquhar}

Abstract: The New Zealand early childhood curriculum, Te Whāriki (Ministry of Education [MoE],1996), is frequently hailed as a community inspired curriculum, praised nationally and internationally for its collaborative development, emancipatory spirit and bicultural approach. In its best form community can be collaborative, consultative, democratic, responsive and inclusive. But community and collaboration can also be about exclusion, alienation and loss. This paper engages with Te Whäriki as a contestable political document. It explores this much acclaimed early childhood curriculum within a politics of community, collaboration and control. Driving the direction of the paper is a call for a revitalised understanding of curriculum as practices of freedom, raising issues of how to work with difference and complexity in a democratic and ethical manner. The paper concludes that although official curriculum is unavoidably about control, there is a world of difference in the ways such control might be exercised. The real curriculum exists where teachers are working with children - it is in the everyday micro-practices that impacts are felt and freedoms played out.

Key words: early childhood, curriculum, politics, practices of freedom, New Zealand.

\section{Introduction}

The meaning of the word curriculum derives from the Latin currere (to run or move quickly) and its associated form curriculum (a racing chariot, or a running course), a racing metaphor that naturalises possible association of curriculum matters with set tracks, hurried progress, competition and contest, and eventual winners and losers. Through common usage, the word has come to signify a course to be followed. Curriculum, in the words 
of Pinar (2009), is "where the world is explained to the young ... where academic knowledge meets the neighbourhood" (pp. 4-5). Democratic governments, he notes, have taken hold of schools - not explicitly in a way that would disclose political agendas, but indirectly, through standardized examinations whereby the curriculum becomes a means to an end. Curriculum has always involved a systematic form of political and social enculturation, intentionally relaying significant knowledge, skills, values and beliefs. In democratic countries like New Zealand, curriculum development can be seen as a form of social politics requiring collaboration between government departments and ministries, and consultation between curriculum developers and teachers, sometimes even consultation with those that curriculum is intended to educate. As one of the key writers of the New Zealand curriculum, Te Whāriki, Helen May (1999) reflected:

the curriculum work I have been involved in over the decade with Margaret Carr is part of the politics of collaboration with government. Curriculum frameworks are about the "regulation" of children even though we called it "empowerment"! We are all engaged in a process of accommodation and resistance. It is important to reflect on what this means politically. (p. 60)

Developing a curriculum invariably involves collaboration, consultation and decision-making about design and scope, about priorities and outcomes, about whose voices are represented in its prescriptions, and ultimately, about how it should be taught. Curriculum is a site of democratic debate and contest, requiring particular ways of thinking about knowledge and learners. It is a highly political serial event, pivotal to governments in the shaping of social and economic priorities. Curriculum is, thus, unavoidably about control, reflecting particular principles and priorities of those engaged in its design, its production and its implementation. Nevertheless, educational institutions have some leeway to interpret and implement curriculum as a way of articulating priorities and requirements for educational focus and performance within the institution. Using the example of the New Zealand early childhood, this paper examines some ways in which control is exercised through curriculum, and suggests a process of exploration appropriate for a rich and varied multicultural society.

In mapping the "shifting landscapes" of the child at the turn of the twentyfirst century, May (1999) argues that the challenge we face in early childhood education is to be active in constructing the future for children, while recognizing that pedagogy is impacted by the political space to which it belongs. In this paper, I take up May's invitation to reflect on the curriculum 
and what it means politically in $2015 / 16$, through an analysis of community and collaboration as a prevalent curriculum discourse in Te Whäriki that pays particular attention to bicultural development. The final section draws on a range of contemporary philosophers and theorists, to reinvigorate curriculum as practices of freedom.

\section{Curriculum as collaboration}

The curriculum document Te Whäriki (MoE, 1996) and related assessment documents Kei Tua o te Pae ${ }^{1}$ (MoE, 2005) engage explicitly with, and can be seen as forms of, participatory democracy, involving notions of reciprocity, sharing and negotiation between child and adult; and mutual reconstruction through community, intergenerational dialogue, project and inquiry (Farquhar, 2010; Reedy, 2013). These texts are grounded in both Western liberal social-democratic traditions and Māori epistemology. The development of these texts involved a commitment to collaboration within the early education community and a lengthy consultation period (Mutch \& Trim, 2013). This collaborative approach is seen by many in the sector as a reason that the new curriculum was so warmly received (Nuttall, 2013; Te One, 2013). The outcome of these initiatives was a democratic, communityfocussed model of bicultural partnership (Ritchie, 2013). Both Te Whāriki and its related assessment documents were designed to support a bicultural immersion approach, effectively giving new status to Māori pedagogy within early childhood education through mainstream early childhood centres and ngā kōhanga reo (Māori immersion early childhood centres).

Thus the curriculum collaboration recognises a long history of social, community and cultural traditions, including the women's movement of the late 1960s-1980s, and Māori tino rangatiratanga (self-determination) of the late 1970s. It reflects aspirations of freedom, and is strongly liberatory in its regard for marginalised groups, including children, women and Māori (May, 2009; Ritchie, 2013). Throughout Te Whäriki, recurring themes of belonging, family, community and relationships can be identified, evoking images of a form of community that emphasises the importance of our social connections. Such a focus both reflects and augments social and political awareness of historical injustices in cultural, social, economic and political arenas. Preceding Te Whäriki's development, a discourse of equality had threaded its way through public policy, underpinned by the newly enacted

Kei Tua o te Pae/Assessment for Learning: Early Childhood Exemplars (Ministry of Education, 2005) are exemplars in a series of booklets that support teachers to understand and strengthen children's learning. They also show how children, parents and whānau can contribute to this assessment and ongoing learning. 
Treaty of Waitangi Act (1975) that recognized the Treaty of Waitangi in New Zealand law for the first time, establishing a Tribunal empowered to investigate various breaches of the Treaty (including later amendments to address historical breaches such as confiscation of land). A political process of restoring lands and resources (still in process today) to tangata whenua (literally, people of the land, i.e., Māori) had its foundation in this period. Increased regard in both social and judicial processes was paid to Māori tino rangatiratanga. An identifiable resurgence of Māori language as an official language of New Zealand accompanied a valuing of the oral tradition of Māori and an emphasis on group culture, dialogue and decision-making, contributing to empowerment of Māori (Reedy, 2013; Ritchie, 2013). Concepts of tino rangatiratanga and whakamana (empowerment) emerged with a focus on Te Reo Māori (the Māori language) and kaupapa (schooling) processes included the beginnings of Te Kōhanga Reo (a total immersion Māori language family programme for young children from birth to six years of age.) Thus, the importance of Māori culture was reified and emphasised in official documents and legislation. The Māori child, seen as a social misfit in the colonialist settler tradition, now had a legitimate identity within Aotearoa New Zealand.

The early childhood curriculum document is in three sections, with one section written in Māori, not as a mere translation but as intentional curriculum for Māori immersion centres based on kaupapa processes, standing testimony to the embeddedness of Te Reo Māori within the document. The joint endeavour involving Te Kōhanga Reo, May and Carr was to develop a Māori curriculum that was not an add-on or integrated, but rather, separate. A significant political statement was being made, with two distinct identities to be retained: Māori and Pākehā. Reedy (2013) argues, "Te Whäriki recognises the child as the living link to the past, the embodiment of the present and the hope for the future" (p. 49). She claims that Te Whäriki is a challenge where

our rights are recognised, and so are the rights of everyone else. For me, ... [it] recognises my right to choose, and your right to choose. It encourages the transmission of my cultural values, my language and tikanga, and your cultural values, your language and customs. It validates my belief systems and your belief systems. (Reedy, 2013, p. 49)

Te Whäriki is a bicultural curriculum, not only in terms of the process of development, but also in its conceptual framework and in its final form and content. Māori values and belief systems based on the cultural and political beliefs of the minority indigenous people sit alongside a Western human- 
ist tradition. The positioning of the Māori oral tradition, with its spiritual commitments, histories and theories, alongside a Pākehā written tradition resulted in an unusual document, with one of its authors signalling that it is explicitly about self-determination "Toku Rangatiratanga na te manamatauranga - knowledge and power set me free" (Reedy, 2013, p. 43).

The origins of Te Whäriki reflect community involvement and engagement, with the resulting document exemplifying the principles which it officially espouses - participation, partnership and consultation. Clearly then, this curriculum is about collaboration. However, a critique remains that the "bicultural nature of curriculum for all early childhood services" (MoE, 1996, p. 7) enframes biculturalism within a monocultural perspective. The discourse of cultural diversity assumes that cultures have universal and identifiable characteristics, an assumption that in effect limits our understanding of difference to that which can be interpreted according to Western cultural values: in terms of progress, rationality, and what is normal. This sanitised view of cultural diversity is then included in curricula, framed as diverse perspectives on human behaviour, but in effect promoting and operating within Western cultural ideas about normalised human progress and development. For example, in her critique of the bicultural child in Te Whäriki, Duhn (2006) suggests that the well-behaved, blended child portrayed in this curriculum continues to promote a liberal romantic, idealised child. This child is neither Māori nor Pākehā, instead the portrayal masks a multitude of differences, rather than reflecting and embracing them. The child is no longer allowed to be different but must instead be blended and homogenised to fit the curriculum.

In contrast, Bhabha $(1990 ; 1994)$ points out the complexity of cultural formations - there is always ambivalence at the site of colonial domination and it is in this ambivalence that culture is at its most productive. Bhabha's notion of cultural difference refers to a process of 'cultural enunciation', establishing parameters of inclusion and exclusion across multiple domains:

It is only when we understand that all cultural statements and systems are constructed in this contradictory and ambivalent space of enunciation, that we begin to understand why hierarchical claims to the inherent originality or 'purity' of cultures are untenable, even before we resort to empirical historical instances that demonstrate their hybridity. (Bhabha, 1994, pp. 54-55) 
Bhabha's focus on cultural enunciation is a useful paradigm to engage with, in the way that it articulates a social and intersubjective understanding of both personal and community identity. An enunciation about childhood or Māori-ness will delineate possibilities, shape meaning, and establish parameters of inclusion and exclusion within relations of power.

Notions of community are, then, contestable, with meanings dependent on one's theoretical orientation. The values underpinning the notion of community in Te Whäriki (a strong sense of belonging, well-being, making contributions, communicating, and exploring through play and family activities) align strongly with the perspective of tangata whenua embedded in its principles of participation, partnership and consultation. Communitarians argue that identity depends on our membership in a community of shared values and meanings, where the self is constituted and defined by social relationships (see, for example, Walzer, 1990). However, the communitarian ideal may be critiqued, in turn, as being undesirably utopian, and politically problematic in its romanticising of the communal and the social at the expense of subjugated minorities and individuals within. Whether or not the politics of community within current curriculum and policy can move beyond the limitations of communitarian and/or liberal politics is perhaps dependent upon the uptake of what is explored below as practices of freedom.

\section{Curriculum as practices of freedom}

The idea of curriculum as collaboration entails quite divergent cultural stories as described in the previous section: on the one hand, communal sharing and participation; on the other hand, division and alienation as individuals and minority groups are further marginalised by monocultural power relations. So far, the paper has portrayed the development and function of Te Whäriki as the privileging of membership in a unitary community of shared values and meanings that can easily ignore concerns of compulsory compliance or alienation. It would be simplistic, though, to suggest there is only one possible way to represent the functions and intentions of curriculum. Working with the idea of curriculum as practices of freedom, this section of the paper develops what might be considered a way forward, drawing on Foucault's (2001) ideas about subjectivity and Ricoeur's (2006) notion of linguistic hospitality, to theorise a practical set of strategies put forward by Connolly (2013), in the form of role experimentation - a way of problematising the taken-for-granted in denaturalising habitual spaces.

Foucault's (1989) study of the subject articulates an ambiguity of the self, both subjecting and subjected, where our own invention is produced by 
the power/knowledge relations of particular discourses. He suggests that we believe ourselves to be rational autonomous individuals with freedom to make certain choices. However, far from being free, we are the result of a highly politicised set of acts that drive us to become particular subjects, generating a particular 'truth' about human beings that becomes normative, self-evident and universal. Subjectivity is a significant element of a government's 'bio-power', a harnessing of individual desire critically important in preserving and extending the State. Bio-power is the term Foucault gives to an elision of the macro management of the population and the micro management of the practices of the individual, in a production of subjectivity, "the process through which results the constitution of a subject, or more exactly, of a subjectivity which is obviously only one of the given possibilities of organising a consciousness of self" (Foucault, 1989, p. 330). This elision of government and individual practices occurs within a social realm. Far from being deterministic, conditions of power/knowledge offer the opportunity for choices through little resistances - the micro-practices and everyday decisions we as teachers make to enact particular practices to reinterpret, resist or subvert particular aspects of official policies.

As a practice of freedom, Foucault (1994) advocates for 'curiosity' as a way to understand that which might appear at first as strange and odd; adopting a 'non-protectionist attitude' that is comfortable with simultaneity - of both this and that:

I dream of a new age of curiosity. We have the technical means; the desire is there; there is an infinity of things to know; the people capable of doing such work exist. So what is our problem? Too little: channels of communication that are too narrow, almost monopolistic, inadequate. We mustn't adopt a protectionist attitude, to stop 'bad' information from invading and stifling the 'good'. Rather, we must increase the possibility for movement backward and forward. This would not lead, as people often fear, to uniformity and levelling-down, but, on the contrary, to simultaneous existence and differentiation of these various networks. (Foucault, 1994, pp. 325-326)

To embrace curiosity is to recognise both temporality and place inherent in community: for one person, community may involve a sense of belonging and well-being; for another, a sense of loss, alienation and insecurity. In this sense, then, a curriculum process may evoke a curiosity, or a caring, to find out "what exists and what might exist" where the partnerships involved in curriculum development work with "a sharpened sense of reality", and 
a "readiness to find what surrounds us strange and odd" (Foucault, 1994, p. 325).

Thus, there is room in our shared reality for continuous interrogation and experimentation - an attitude of critique that would involve curriculummakers in a practice of freedom where freedom is in the very act of resistance. Freedom, in this sense, is not about removing barriers, but about causing small movements through constant agitations, through thinking differently, and through entertaining multiple possibilities in arriving at any curriculum prescription.

Ricoeur (2006) further illuminates the territory of dialectical difficulty, with his philosophy of linguistic hospitality: "the act of inhabiting the word of the Other paralleled by the act of receiving the word of the Other into one's own home, one's own dwelling" (p. xvi). Linguistic hospitality recognises a small window of opportunity where two worlds may not necessarily agree but can mutually co-exist, an attitude involving philosophical play that neither requires a consensus nor allows an impasse. Difference is to be neither overcome nor normalised, but maintained as an important part of human belonging. The game is not to convince someone that a particular perspective is better than another, but rather to hear the various perspectives in order to understand better (Ricoeur, 1992). The requirement is not to co-opt the experience of another, but to privilege conditions of disagreement so that the various perspectives mutually co-exist. Ricoeur is seeking an agonistic engagement in which participants encounter familiarity and strangeness, alienation and misunderstanding - a recognition that authentic relationships exist in tensional spaces. Ricoeur's critical theorising argues that in modern society, surplus of economic thinking forms a kind of "barbarism" (Ricoeur, 2000), a condition in which we are consumed by high speed economic and technological advancements that require extra vigilance.

Further advancing this theme of difference and agonistic engagement, Mouffe (1988) proposes a radical form of democracy which entails giving up the abstract idea of a universal human nature. She advocates instead a new kind of articulation between the universal and the particular, acknowledging heterogeneity and leaving room for plurality and conflict. The human subject is thus shifting and changing in dialogue with its social surroundings:

we are in fact always multiple and contradictory subjects, inhabitants of a diversity of communities (as many, really, as the social relations in which we participate and the subject-positions they define), construct- 
ed by a variety of discourses and precariously and temporarily sutured at the intersection of those subject-positions. (Mouffe, 1988, p. 44)

Such an articulation is not about the power of the majority and the rights of minorities. It is not defined by participation or consensus or by insistence on rational clarity, but by respect for diversity: of beliefs, origins, opinions and values. This diversity is necessarily a space of tension and conflict, of mutual recognition of the other, and cannot be reduced to a single principle. Instead, as Touraine argues, we need to build an increasingly open world that is also as diverse as possible, since without unity, communication becomes impossible; without diversity, death prevails. We cannot, he argues, sacrifice one for the sake of the other:

Democracy should no longer be defined as the triumph of the universal over the particularised, but as a set of institutional guarantees that makes it possible to reconcile the unity of instrumental reason with the diversity of practical experience, and to bring together social exchange and political freedom. (Touraine, 1997, p. 3)

The myth of a unitary subject gives way here to a subject embedded within particular social or cultural loyalties, inevitably the site of tension, and the best hope for any personal and collective opposition to domination and social control without requiring the total dissolution of society. Within this engagement, "every social actor must recognise that the other has the right to form projects and preserve memories" (Touraine, 1997, p. 186). This is not a call for an open political market, but for the creative liberty of the subject, where the subject's ability to be a social actor and to modify the environment is within a clear territory of free creativity.

It would be too easy to sign off with a utopian vision of an alternate reality, with little indication of what practical implementation might look like. Usefully, Connolly's "existential gratitude" (2013) offers such a way to reinvigorate understandings of Te Whäriki and democratic contestability of curriculum, through a new mode of curriculum resistance. An ethos of existential gratitude makes us alert to the fragility of things, to "mobilise surplus energies needed to work experimentally upon the institutional roles that help to situate us culturally" (p. 181). Connolly suggests starting with the positive possibilities of micro-experimentation, arguing that there are significant relays between role performance, self-identity, and the formation of larger political constellations. What he offers is a practical set of strategies to denaturalise habitual spaces and to "set preconditions for 
constituency participation in more robust political movements" [author's emphasis] (p. 184).

Our lives are messages. Role experimentation can disrupt and redirect the flow of authority, habit, institutional regularity, and future projection. It can also encourage others to look more closely at their own performances....Such experiments can also set the stage for more adventurous and larger scale actions ... Indeed as such oscillations proceed, moments of stuttering, unfocused shame, laughter and hesitation periodically arise, drawn from the element of noise that inhabits the spaces between roles and role bearers. (Connolly, 2013, p. 185)

Such a configuration invites us to explore more closely how existing definitions and practices are presupposed and enforced, how they contribute to the fragility of things as they simultaneously draw our attentions away from the ways such practices are made routine. In deference to the 'micro' component of micro-practices, Connolly acknowledges that such experiments are minor moments, but argues that an accumulation of minor moments can jostle settled habits of perception, encourage a readiness to become more exploratory, and can extend the time horizon within which we think and act. We are not talking here about mass movements, large scale revolution, or even a formulaic set of instructions for resistance. What is invited is quite personal, as we begin to make ourselves and our engagements more experimental rather than simply falling into a ready-made set of role expectations: As Connolly suggests a place where we "become what Nietzsche calls 'our own guinea pigs' rather than merely being the guinea pigs of those in charge of these institutions" (Connolly, 2013, p. 188).

Acknowledging the reality of curriculum contestation as a deeply political process, Moss (2007) points out that the prospect of engaging politically may be somewhat daunting. The political process may appear far removed from curriculum design and implementation needs, but Moss still emphasises the need to make a strong case for pluralist perspectives. Drawing upon Mouffe's radical democracy, he turns his back on any form of 'consensus without exclusion' as a form of assimilation - as domesticating differences and diffusing antagonisms. Instead, he argues, a condition for democracy should be that it recognises and legitimates conflict and different perspectives without requiring domination.

The prospect of engaging politically may be daunting and even a touch naïve as the requirement of openness, vulnerability and recognition is 
far removed from political drawing boards, however, he argues politicians, policy makers and the media should be left with 'no excuse for believing that there is only one perspective on early childhood education, only one narrative to be told. (p. 237)

The care and education of young children is a deeply engaging emotional public frontier that confronts and challenges rationalist, abstract, and impersonal systems of thought, with far-reaching social, political and ethical implications. Moss \& Petrie (2002) argue for a concept of children's space - a sense of curriculum that is deeply contestable predicated on a revitalisation of democracy. The case is made for community - not recreated from the top, but "negotiated, justified and experienced" (p. 40) and specifically, involving children:

a cultural space, where values, rights and cultures are created; and a discursive space for differing perspectives and forms of expression, where there is room for dialogue, confrontation...deliberation and critical thinking, where children and others can speak and be heard. (p. 9)

The concept of children's space is linked to an ethos of recognition involving various acts of linguistic hospitality including an engagement between child and adult, raising complex issues of how to work with "diversity and complexity, uncertainty and plurality" in a democratic and ethical manner (Moss \& Petrie , 2002, p. 13).

\section{Concluding thoughts: Curriculum as contest}

The paper has argued that curriculum is unavoidably about control, but that there is a world of difference in the ways such control might be exercised. The collaborative effort behind the development of Te Whäriki may have generated a model curriculum for those with aspirations for a rich and varied multicultural society. A communitarian focus on shared values and meanings underlines the importance of social relationships in both the production of curriculum and children's education. Despite the focus on collaboration, May (1999) is clear that control is an important feature of curriculum - accommodating and resisting government and regulating children under the guise of labels like empowerment. Further control is exerted at the level of political expectations on our educational institutions. In New Zealand, there is already talk of standardising early childhood curriculum and assessment, so we can expect to see tighter prescription and controls in early childhood education over coming years. 
The representation of curriculum as collaboration and control is borne out in the design of curriculum to set prescriptions for the focus of early childhood education, establish a common vision of the good society, regulate children and their families, and promote curriculum dialogue within prescribed boundaries. Representing curriculum as practices of freedom, however, provides quite a different emphasis from official statements emanating from government, or published documents that prescribe what curriculum should be. It is unlikely that the official curriculum will pave the way for the kind of experimentation advocated by Connolly and the concomitant unsettling of existing definitions and practices that sustain prevailing government edicts for educational outcomes. Yet, all is not set in concrete. The real curriculum exists where teachers are working with children - it is in the everyday micro-practices that impacts are felt and freedoms played out. It is in these micro-spaces that there is still room for curiosity, for linguistic hospitality, and for plurality of subjectivities. It is here that the real contest begins.

\section{References}

Bhabha, H. (1990). Nation and narration. New York: Routledge.

Bhabha, H. (1994). The location of culture. New York: Routledge.

Connolly, W. (2013). The fragility of things. Self-organizing process, neoliberal fantasies, and democratic activism. Durham \& London: Duke University Press.

Duhn, I. (2006). The making of global citizens: Traces of cosmopolitanism in the New Zealand early childhood curriculum, Te Whāriki. Contemporary Issues in Early Childhood, 7(3), 191-202.

Farquhar, S. (2010). Ricoeur, identity and early childhood. Maryland: Rowman \& Littlefield.

Foucault, M. (1989). Foucault live: Interviews, 1966-84 (J. Johnston, Trans.). New York: Semiotext(e).

Foucault, M. (1994). The masked philosopher. In P. Rabinow (Ed.), Ethics. The essential works 1 (pp. 321-328). London: Penguin.

Foucault, M. (2001). The subject and power. In J. Faubion (Ed.), Power: The essential works 3 (pp. 326-48). London: Penguin.

Ministry of Education. (2005). Kei tua o te pae assessment for learning: Early childhood exemplars. Wellington: Learning Media.

Ministry of Education. (1996). Te Whāriki: He Whāriki Matauranga Mō Ngā Mokopuna o Aotearoa, Early Childhood Curriculum. Wellington: Learning Media.

May, H. (2009). Politics in the playground: The World of Early Childhood Education in New Zealand. Dunedin: Otago University Press.

May, H. (1999). "ece@2000.aotearoa.nz: Mapping the landscape of the "century of the child'." New Zealand Annual Review of Education, 9, 117-132. 
Moss, P. (2007). Meetings across the paradigmatic divide. Educational Philosophy and Theory, 39(3), 229-245.

Moss, P., \& Petrie, P. (2002). From children's services to children's spaces. Public policy, children and childhood. London: RoutledgeFalmer.

Mouffe, C. (1988). Radical democracy: Modern or postmodern? In A. Ross (Ed.), Universal abandon? The politics of postmodernism. Edinburgh: Edinburgh University Press.

Mutch, C., \& Trim, B. (2013). Improvement, accountability and sustainability: A comparison of developments in the early childhood and schooling sectors. In J. Nuttall (Ed.), Weaving Te Whāriki. New Zealand's early childhood curriculum document in theory and practice. (pp. 71-91). Wellington: New Zealand Council for Educational Research.

Nuttall, J. (2013). Weaving Te Whāriki. Aotearoa New Zealand's early childhood curriculum document in theory and practice. Wellington: New Zealand Council for Educational Research.

Pinar, W. (2009). The worldliness of a cosmopolitan education. Passionate lives in public service. New York: Routledge.

Reedy, T. (2013). Toku rangatiratanga na te mana-matauranga. 'Knowledge and power set me free ...'. In J. Nuttall (Ed.), Weaving Te Whāriki. Aotearoa New Zealand's early childhood curriculum document in theory and practice (pp. 35-53). Wellington: New Zealand Council for Educational Research.

Ricoeur, P. (2006). On Translation. (E. Brennan, Trans.). London: Routledge.

Ricoeur, P. (2000). The just. (D. Pellauer, Trans.). Chicago: University of Chicago Press.

Ricoeur, P. (1992). Oneself as another. (K. Blamey, Trans.). Chicago: University of Chicago Press.

Ritchie, J. (2013). Te Whāriki and the promise of early childhood care and education grounded in a commitment to Te Tiriti o Waitangi. In J. Nuttall (Ed.), Weaving Te Whäriki. Aotearoa New Zealand's early childhood curriculum document in theory and practice. (pp. 141-156). Wellington: New Zealand Council for Educational Research. Te One, S. (2013). The context for Te Whāriki: Contemporary issues of influence. In J. Nuttall (Ed.), Weaving Te Whāriki. Aotearoa New Zealand's early childhood curriculum document in theory and practice. (pp. 7-34). Wellington: New Zealand Council for Educational Research.

Touraine, A. (1997). What is democracy? (Transl. D. Macey). Boulder, CO: Westview Press HarperCollins.

Treaty of Waitangi Act, No. 114. (1985). Retrieved from http://www.legislation.govt. nz/act/public/1975/0114/latest/DLM435368.html?src=qs

Walzer, M. (1990). The communitarian critique of liberalism. Political Theory, 18(1), 6-23. 


\section{Author:}

Sandy Farquhar, Ph.D.

University of Auckland

Faculty of Education and Social Work

School of Learning, Development and Professional Practice

78 Epsom Avenue

Auckland

1035

New Zealand

Email: s.farquhar@auckland.ac.nz 